\title{
Kontribusi Lingkungan Organisasi Terhadap Peningkatan Kualitas Aplikasi Keuangan Survey Pada Perbankan BUMN
}

\author{
Lilis Puspitawati ${ }^{*}$, Hilmi ${ }^{2}$, Popy Gurning ${ }^{3,}$ dan Nanang Suryana ${ }^{4}$ \\ ${ }^{1,3}$ Program Studi Akuntansi FEB, Universitas Komputer Indonesia \\ ${ }^{2}$ Program studi akuntansi, Fakultas Ekonomi dan Bisnis, Universitas malikul saleh-Aceh \\ ${ }^{4}$ Program Studi Prodi Teknik Industri, Fakultas Rekayasa Industri, Telkom University

\begin{abstract}
Email Address:
lilis.puspitawati@email.unikom.ac.id ${ }^{1 *}$, Hilmi@unimal.ac.id,
\end{abstract} \\ popygurning@mahasiswa.unikom.ac.id ${ }^{2}$ nanang.suryana@yahoo.com ${ }^{3}$
}

\begin{abstract}
The quality of the financial aplication is highly dependent on the organizational environment in which the information system is used. This concept is in line with the facts found in the field that until now the quality of accounting information system applications used by various companies is still relatively low because they often experience errors and are not well integrated which have an impact on the low quality of accounting information. This study aims to determine whether organizational environmental factors in this case represented by organizational structure and culture still have an influence on the quality of accounting information systems. This research uses descriptive verification method. The sample size in this study was 30 employees of operational units who use accounting information system applications at state-owned banks with branch offices in Bandung, this study uses primary data collected by distributing questionnaires. Statistical testing used is PLS SEM and hypothesis testing using PLS 3.0 smart software. The results of this study indicate that there is consistency with the results of previous studies that the increasing implementation of organizational culture has an impact on increasing the quality of accounting information systems, and the more effective organizational structure has an impact on the quality of accounting information systems.
\end{abstract}

Keywords: Organizational Culture, Organizational Structure, Quality of Accounting Information Systems.

Abstrak: Penerapan Aplikasi keuangan perusahaan tergantung dari Lingkungan organisasi dimana organisasi tersebut berada. Konsep ini sejalan dengan fakta yang ditemukan di lapangan bahwa sampai saat ini kualitas aplikasi keuangan berbagai perusahaan masih rendah dan sering mengalami gangguan, tidak terintegrasi kurang aman sehingga kualitas informasi keuangna yang dihasilkan menjadi rendah. Penelitian ini bertujuan untuk menguji model teori terkait kontribusi lingkungan organisasi (struktur dan budaya organisasi) terhadap peningkatan kualitas aplikasi keuangan. Kajian ini menggunakan metode deskriptif verifikatif. Ukuran sampel yang digunakan 30 user aplikasi keuangan Perbankan BUMN di Kota Bandung, model teori diuji dengan SEM PLS 3.0. Hasil penelitian ini membuktikan adanya konsistensi dengan hasil penelitian terdahulu bahwa semakin emeningkatnya implementasi budaya organisasi berdampak pada peningkatan kualitas aplikasi keuangan, dan struktur organisasi yang efektif berdampak terhadap peningkatan kualitas aplikasi keuangan.

Kata Kunci: Budaya Organisasi, Struktur Organisasi, Kualitas Aplikasi keuangan. 


\section{PENDAHULUAN}

Kemajuan Teknologi Informasi berdampak pada semua aspek termasuk dalam aspek ekonomi dan Bisnis. Perkembangan IT yang semakin marak didunia bisnis tersebut di tenggarai oleh persaingan usaha semakin tajam dalam dunia industri. Adanya persaingan usaha menuntut para pelaku usaha untuk selalu berinovasi demi mempertahankan eksistensi usaha dan pangsa pasar agar selalu dibutuhkan oleh konsumen. Kondisi tersebut menghasilkan Iklim kompetisi yang semakin tajam antar para pelaku usaha untuk meraih keunggulan kompetitif. Untuk menjadi pemenang dalam persaingan bisnis, para pelaku usaha dituntut untuk mampu menciptakan efisiensi dan efektifitas penggunaan dari sumber daya perusahaan, dan hal tersebut dapat terealisasi bila pengolahan transaksi bisnis perusahaan menggunakan sistem informasi. Entitas bisnis setiap saat melakukan pengolahan data data yang bersifat autentik dimulai dari tingkat manajemen yang teratas hingga yang terendah. Penggunaan sistem informasi membantu aktivitas pengolahan data dapat dilakukan secara efektif dan efisien sehingga mampu menghasilkan berbagai informasi yang memiliki value added dalam pengambilan keputusan strategis (Lilis Puspitawati, 2021).

Menurut (Chandra, 2018), Sistem Informasi Akuntansi merupakan bagian sistem informasi yang memiliki fungsi mengolah data/transaksi keuangan menjadi informasi akuntansi yang biasanya publikasi laporan keuangan untuk para stakeholders. Kualitas informasi akuntansi yang dihasilkan dari laporan keuangan sangat dipengaruhi oleh Kualitas sistem informasi akuntansi yang digunakan suatu perusahaan dan kondisi tersebut mencerminkan kinerja suatu perusahaan yang dapat berdampak pada performa perusahaan tersebut. Selanjutnya menurut (Azhar, 2013), Sistem informasi akuntansi dapat pula dinyatakan sebagai aplikasi keuangan yang merupakan integrasi harmonis dari sekelompok sub sistem yang memiliki tujuan untuk mengolah data menjadi informasi yang dapat digunakan untuk pengambilan keputusan para penggunanya (Azhar, 2013). Keberadaan sistem informasi pada hakekatnya berfungsi untuk membantu personil organisasi dalam mengolah berbagai data menjadi informasi yang memiliki nilai tambah berharga yang bermanfaat bagi para penggunanya.

(Azhar, 2013), selanjutnya berpendapat kualitas aplikasi keuangan mengacu pada pemahaman bagaimana semua unsur, elemen maupun komponen terintegrasi untuk menghasilkan informasi akuntansi berkualitas yang digunakan dalam memperbaiki efisiensi dan efektifitas proses bisnis Hal senada dinyatakan oleh (Arlis, 2016), bahwa kualitas aplikasi keuangan merupakan suatu tolak ukur yang digunakan manajer untuk mengurangi risiko ketidakpastian, mendukung pengambilan keputusan, dan mendorong efektifitas dan efisiensi aktivitas bisnis. Kualitas Apliksi keuangan dapat dinilai sebagai tolak ukur keberhasilan perusahaan dalam menghasilkan informasi keuangan yang memiliki nilai tambah yang bermanfaat untuk berbagai penggunanya.

Kondisi aplikasi keuangan yang digunakan oleh berbagai perbankan di Indonesia saat ini belum menunjukan kondisi yang baik dan masih sering mengalami kendala. Menurut (Ruby Alamsyah, 2019), aplikasi keuangan yang digunakan oleh Bank Mandiri masih sering mengalami gangguan (error system) ketika proses pemindahan data melalui aplikasi pada saat tutup buku. Kejadian Error system tersebut diprediksi mengakibatkan perubahan saldo rekening nasabah bank mandiri sekitar $10 \%$. Kondisi ini menunjukan aplikasi keuangan yang digunakan perbankan belum sepenuhnya handal. 
Kendala yang lainnya adalah aplikasi keuangan yang digunakan saat ini masih belum dapat terintegrasi dengan baik sehingga mempengaruhi kualitas data yang dihasilkan. Kondisi ini disampaikan oleh (Moermahadi Soerja, 2018) dalam kapasitasnya sebagai ketua Badan Pemeriksa Keuangan RI yang menyoroti penggunaan aplikasi keuangan Custom Excise Information System and Automation (CEISA), pada Kementerian Perdagangan dalam kegiatan impor barang menggunakan dan aplikasi tersebut pada saat ini belum sepenuhnya dapat terintegrasi dengan portal Indonesia National Single Widow (INSW) sehingga berpengaruh terhdap akurasi data yang dihasilkannya.

Beberapa penelitian terdahulu menunjukan bahwa kualitas aplikasi keuangan diperngaruhi oleh banyak faktor diantaranya oleh faktor budaya organisasi dan struktur organisasi yang diterapkan diperusahaan tersebut. Hasil Penelitian (Strumickas dan Valanciene, 2010), menunjukkan bahwa kualitas aplikasi keuangan pada 7 perusahaan di Lithuania sangat dipengaruhi oleh struktur organisasi. Selanjutnya penelitian yang dilakukan oleh Yarmohammad Zahed pada tahun 2011 menghasilkan bukti empiris bahwa semua dimensi pada struktur organisasi berpengaruh positif dan signifikan terhadap kualitas aplikasi keuangan. Demikian pula dengan penelitian (Hammad et al., 2013) yang menemukan bahwa struktur organisasi merupakan faktor esensial bagi kualitas aplikasi keuangan pada 50 rumah sakit di Iran.

Selain Struktur Organisasi, para peneliti terdahulu berhasil membuktikan budaya organisasi berkontribusi dalam meningkatkan efektifitas aplikasi keuangan pada berbagai perusahaan. Studi yang dilakukan oleh (Xu, 2011) berhasil membuktikan budaya yang dianut oleh suatu organisasi berpengaruh terhadap keberhasilan penerapan aplikasi keuangan yang digunakan perusahaan, selanjutnya (Xu, 2011) menyatakan pula bahwa memberikan perhatian yang optimal terhadap keberhasilan penerapan budaya organisasi merupakan salah satu upaya untuk mencapai kesuksesan penggunaan aplikasi keuangan dalam suatu organisasi. Studi yang dilakukan oleh Busco \& Scapens pada tahun 2011 pada organisasi sector public berhasil membuktikan pula bahwa penerapan budaya organisasi berkontribusi dalam keberhasilan pengembangan dan penerapan Aplikasi keuangan. Kemudian hasil studi yang dilakukan oleh Gajendran dan Brewer pada tahun 2012 membuktikan bahwa mengadopsi kemajuan IT misalnya aplikasi keuangan membutuhkan dukungan berupa pertimbangan yang komprehensip terkait penerapan budaya organisasi yang berlaku di perusahaan pada tahap perancangan dan implementasi.

Telah banyak peneliti yang mengkaji pengaruh Budaya organisasi dan struktur organisasi terhadap kesuksesan penerapan aplikasi keuangan masih teruji secara parsial, oleh karena itu dilakukan penelitian kembali dengan topik yang sama dengan tujuan untuk menguji model konseptual secara simultan apakah variabel Budaya Organiasasi dan Struktur Organisasi masih memiliki pengaruh terhadap Kualitas aplikasi keuangan serta untuk mengetahu seberapa besar pengaruh budaya organisasi dan Struktur Organisasi terhadap kualitas aplikasi keuangan. 


\section{KAJIAN TEORI}

Budaya Organisasi. Budaya merupakan pedoman hidup atau cara bertindak yang terdiri dari aturan-aturan sosial tidak tertulis yang berlaku di suatu kelompok masyarakat. Budaya dapat pula diartikan sebagai sistem nilai masyarakat, pola perilaku, kepercayaan yang berlaku pada suatu kelompok atau organisasi serta semua pemikiran yang menggambarkan nilai-nilai yang dianut bersama oleh suatu kelompok dan cenderung bertahan walaupun anggota kelompok sudah berubah (Luthans, 2008). Selanjutnya (Stair et al., 2012) berpendapat bahwa Budaya (culture) merupakan seperangkat pemahaman dan asumsiasumsi pokok yang dianut oleh suatu kelompok (suku, etis atau negara).

Bila dikaitkan dengan Organisasi maka budaya dapat dinyatakan sebagai pedoman dalam menentukan kebijakan, cara bertindak, pola berperilaku yang terdiri dari aturanaturan, nilai-nilai dan norma-norma yang diberlakukan dalam suatu kelompok secara formal dan legal. Kemudian (Kreitner dan Kinichi, 2003) mengartikan budaya organisasi sebagai salah satu wujud anggapan yang dimiliki, diterima secara implisit oleh kelompok dan menentukan bagaimana kelompok tersebut rasakan, pikirkan dan bereaksi terhadap lingkungan yang beraneka ragam

(Robbins dan Judge, 2015) selanjutnya mendefinisikan budaya organisasi sebagai suatu sistem yang dianut bersama oleh anggota-anggota organisasi yang menjadi ciri khas organisasi. Selanjutnya (Edy Sutrisno, 2015) mendefinisikan budaya organisasi merupakan spirit organisasi yang dapat menggerakan individu dalam organisasi untuk melakukan aktivitas kerja yang memiliki harmoni yang sama. Berdasarkan kedua definisi tersebut maka dapat dinyatakan budaya organisasi merupakan suatu pola pikir atau asumsi dasar yang harus dimiliki, dipelajari dan diterima oleh anggota dalam suatu entitas dalam beraktivitas, memecahkan masalah serta beradaptasi dengan lingkungan eksternal maupun internal. Selanjutnya (Robbin dan Judge, 2018), menjelaskan budaya organisasi dapat diukur melalui karakteristik budaya organisasi yaitu (1) Inovasi dan pengambilan risiko, (2) Perhatian terhadap detail, (3) Orientasi hasil, (4) Orientasi orang, (5) Orientasi tim, (6) Agresivitas dan (7) Stabilitas.

Struktur Organisasi. Organisasi perlu menyelaraskan berbagai pekerjaan menjadi bagianbagian yang dapat dikelola dan menyelaraskan bagian-bagian tersebut agar para individu dapat saling berkoordinasi demi tercapainya tujuan perusahaan secara efektif dan optimal. Penyelarasan ini digambarkan dalam suatu struktur/bagan organisasi (Campbell dan Craig, 2005). Struktur organisasi digambarkan dalam bentuk bagan organisasi (Griffin dan Moorhead, 2014).

Bagan organisasi (organizational chart) menggambarkan sisi visual dari sekumpulan aktivitas-aktivitas dan proses-proses yang terdapat dalam organisasi (Daft, 2010). Struktur organisasi merupakan salah satu lingkungan dalam organisasi. Struktur organisasi mengatur aliran informasi, tugas/kegiatan, tanggung-jawab dan wewenang yang tersebar di dalam seluruh tingkatan organisasi, dengan kata lain struktur organisasi terkait dengan pertanyaanpertanyaan seperti siapa melapor kepada siapa, siapa melakukan apa serta dimana pekerjaan dilakukan (William, 2015).

(Colquitt et al., 2015) mendeskripsikan struktur organisasi sebagai uraian tugas dan tanggung jawab yang harus dikoordinasikan antara bagian /kelompok dalam suatu entitas/organisasi. Struktur organisasi dapat digambarkan dalam bentuk bagan/diagram 
organisasi yang menjelaskan tugas dan tanggung jawab yang harus dipahami dan dilaksanakan oleh seluruh anggota entitas/organisasi. Kemudian (Robbins dan Coulter, 2016) menyatakan struktur organisasi adalah bentuk formalitas tugas dan tanggung jawab setiap bagian dalam sebuah organisasi. Selanjuatnya, (Robbins et al., 2015), berpendapat bahwa stukrtur organisasi dapat diukur melalui indikator: (1) Spesialisasi Kerja, (2) Departementalisasi, (3) Rantai Komando, (4) Rentang Kontrol, (5) Sentralisasi dan Desentralisasi dan (6) Formalisasi.

Selanjutnya dapat disimpulkan struktur organisasi merupakan susunan uraian pekerjaan/tugas yang menggambarkan hubungan antar bagian berdasarkan posisi yang telah ditetapkan oleh organisasi yang mengacu pada spesifikasi keahliannya masing-masing dalam menjalankan kegiatan-kegiatan operasional atau dalam mencapai tujuan organisasi yang di harapkan.

Kualitas Aplikasi Keuangan. Aplikasi keuangan merupakan praktik dari implementasi sistem informasi Akuntansi yang merupukan sekumpulan peralatan, pengguna, data, prosedur dan IT yang berfungsi untuk mengolah data keuangan menjadi informasi keuangan yang dapat digunakan berbagai penggunanya. (Lilis, 2021) mendefinisikan Aplikasi keuangan merupakan suatu sistem informasi akuntansi/keuangan yang diwujudkan dalam bentuk perangkat lunak berbasis IT yang difungsikan untuk membantu pencatatan dan pelaporan transaksi keuangan dalam suatu organisasi.

Secara konseptual sistem informasi akuntansi telah didefinisikan oleh berbagai sumber. Menurut (Anastiasia dan Lilis, 2011) menyatakan bahwa sistem informasi akuntansi adalah Sistem yang bertujuan untuk mengumpulkan dan memproses data serta melaporkan informasi yang berkaitan dengan transaksi keuangan. Sedangkan menurut (Lilis dan Sri, 2011) sistem informasi akuntansi adalah sistem yang mengorganisasikan seluruh sumber daya organisasi untuk menghasilkan informasi keuangan yang dibutuhkan dalam pengambilan keputuasn strategis. Berdasarkan uraian diatas maka dapat disimpulkan bahwa sistem informasi akuntansi adalah suatu sistem yang didesain untuk melakukan fungsi pengolahan data keuangan dan pelaporan informasi keuangan suatu entitas.

Konsep kualitas sistem informasi Akuntansi didopsi dari konsep kualitas sistem informasi yang telah dikembangkan oleh para ahli dan diuji oleh banyak peneliti terdahulu dalam mengukur konsep kualitas informasi akuntansi. Konsep kualitas sistem informasi telah banyak dikaji oleh para ahli sejak tahun 1992. Model kesuksesan sistem informasi yang dikemukakan (De Lone dan McLean, 1992) telah banyak digunakan sebagai dasar dari sejumlah penelitian dalam menilai kualitas atau kesuksesan/efektifitas implementasi berbagai jenis sistem informasi.

Selanjutnya (Deghanzade et al., 2011) berpendapat bahwa kualitas sistem informasi akuntansi merupakan kinerja sistem informasi yang mampu menciptakan kepuasaan bagi pengguna informasi atas informasi yang diinginkannya. Demikian pula menurut Nicolau (2000) kualitas/efektifitas sistem informasi akuntansi merupakan cerminan kepuasan pengguna sistem informasi atau persepsi pengguna sistem informasi terhadap informasi yang diinginkan.

Senada dengan pendapat tersebut (Post dan Anderson, 2003) menyatakan kualitas sistem informasi dapat diukur melalui kemampuan sistem informasi dalam menyediakan informasi yang dibutuhkan oleh manajer pada waktu yang tepat dan sesuai. Demikian pula (Hoque, 2003) berpendapat, kualitas sistem informasi akuntansi merupakan kondisi di mana 
sistem informasi akuntansi dapat menghasilkan informasi akuntansi manajemen yang berguna bagi manajer dalam menjalankan proses manajemen. Pernyataan yang sama dikemukakan pula oleh (Sacer et al., 2006), bahwa kualitas sistem informasi merupakan suatu kondisi dimana sistem informasi akuntansi dapat menghasilkan informasi akuntansi yang sesuai dengan kebutuhan user. Informasi akuntansi yang berkualitas diperoleh dari hasil penerapan sistem informasi akuntansi yang berkualitas.

Selanjuntya (Azhar, 2013) menyatakan tolak ukur kualitas aplikasi keuangan dinilai dari bersinergi harmonis yang dihasilkan dari seluruh komponen yang digunakan aplikasi keuangan dalam mencapai tujuan strategisnya. Sedangkan menurut (Krismiaji, 2015) kualitas aplikasi keuangan ditandai dengan keberhasilan suatu aplikasi keuangan dalam mengelola data keuangan menjadi informasi yang bermanfaat bagi para pembuat keputusan.

Berdasarkan berbagai pendapat tersebut dapat dikatakan bahwa kualitas sistem informasi akuntansi merupakan ukuran kinerja atau kemampuan sistem informasi akuntansi untuk menghasilkan informasi yang tepat waktu serta mampu memenuhi kepuasan pengguna informasi terhadap kesesuaian informasi akuntansi yang diinginkan

Kualitas Aplikasi keuangan dapat diukur dengan menggunakan ciri-ciri sebagai berikut: (1) Ketersediaan (2) Keamanan, (3) Pemeliharaan dan (4) Terintegrasi. Uraian konsep tersebut menunjukan bahwa kualitas aplikasi keuangan adalah suatu tolak ukur keberhasilan penggunaan sistem informasi akuntansi yang tersedia setiap saat (handal), aman digunakan, dan terintegrasi serta mampu membantu entitas dalam menyediakan informasi keuangan yang akurat, relevan, tepat waktu dan lengkap.

Budaya Organisasi Dan Pengaruhnya Terhadap Kualitas Aplikasi Keuangan. Setiap organisasi memiliki budaya yang unik dan terdiri dari sekumpulan elemen seperti asumsi dasar, nilai, norma dan cara dalam melakukan sesuatu, yang diterima oleh hampir seluruh anggota organisasi. Komponen budaya organisasi tersebut digunakan oleh berbagai individu organisasi dalam mencapai tujuan perusahaan. Budaya organisasi akan menentukan arah, tujuan, strategi dan kebijakan perusahaan dimasa yang akan datang. Termasuk budaya penggunaan sistem informasi dalam membantu aktivitas operasional perusahaan sehari-hari merupakan salah satu bentuk implementasi dari budaya organisasi yang berlaku di perusahaan (Lilis, 2021)

Kontribusi budaya organisasi terhadap kualitas aplikasi keuangan dinyatakan oleh (Turban dan Volonino, 2015) bahwa Keberhasilan penggunaan aplikasi keuangan sangat ditentukan oleh keterkaitan aplikasi keuangan tersebut dengan pengguna, proses bisnis serta budaya organisasi dimana aplikasi keuangan tersebut digunakan. Pendapat tersebut selanjutnya dinyatakan pula oleh (Kendall dan Kendall, 2011), bahwa organisasi terdiri dari berbagai subkultur yang harus dikenali, dipahami dan digunakan oleh anggota organisasi yang berkontribusi terhadap perubahan perilaku anggota dalam melaksanakan berbagai aktivitas termasuk pula dalam menggunakan aplikasi keuangan yang disediakan oleh suatu organisasi.

Budaya organisasi dapat pula mempengaruhi desain sistem informasi akuntansi karena dalam budaya organisasi berisi norma/nilai/aturan yang merupakan landasan utama atau pedoman bagi perusahaan dalam menentukan arah dan kebijakan perusahaan di masa yang akan datang. Nilai/norma/aturan tersebut akan memandu suatu organisasi dalam menuntun perusahaan dalam mengambil kebijakan dan strategi yang tepat dalam mencapai tujuan organisasi. Budaya organisasi juga akan menuntun organisasi sangat berhubungan 
dengan sumber daya manusia (SDM) yang digunakan dalam suatu organisasi. Nilai/norma/aturan yang ditanamkan sebagai budaya dalam suatu organisasi akan di anut atau tercermin dari perilaku/sikap/etika Sumber daya manusia (SDM) yang ada dalam suatu organisasi tersebut. Perilaku/Sikap/etika dari SDM dalam organisasi akan berdampak terhadap implementasi sistem informasi akuntansi dalam suatu perusahaan. Apabila suatu perusahaan sudah menerapkan nilai/norma yang tinggi dalam hal kebijakan penggunaan sistem informasi maka SDM dalam organisasi akan melaksanakan kebijakan implementasi Sistem informasi itu dengan perilaku/sikap/etika yang baik (patuh dan bertanggung jawab), sehingga aplikasi Sistem informasi Akuntansi tersebut dapat sukses diterapkan dalam suatu organisasi (Lilis, 2021).

Konsep tersebut selanjutnya di kaji ulang oleh berbagai peneliti menggambarkan hasil yang beragam. Penelitian (Rahayu, Puspitawati dan Anggadini, 2014) menunjukkan budaya organisasi berkontribusi terhadap kualitas Aplikasi keuangan dan Manajemen pada entitas perguruan tinggi. Selanjutnya hasil studi yang dilakukan oleh (Lilis dan Nurshalihat, 2020) menunjukkan bukti empiris budaya organisasi memiliki kontribusi yang signifikan terhadap kualitas aplikasi pembayaran tiket (e-ticket) studi kasus pada PT KAI di Indonesia. Kemudian hasil penelitian (Inta, 2015) menunjukkan budaya organisasi berpengaruh terhadap kualitas aplikasi keuangan.

Stuktur Organisasi Dan Pengaruhnya Terhadap Aplikasi Keuangan. Struktur organisasi memberikan kontribusi terhadap aplikasi keuangan dalam hal memfasilitasi penyediaan informasi dengan cara memperluas jaringan/distribusi informasi pada berbagai tingkatan organisasi, sehingga mampu memfasilitasi karyawan yang berada pada level terendah untuk berkontribusi dalam proses pengambilan keputusan (Laudon dan Laudon, 2012). Selanjutnya (Bodnar et al., 2010), menyatakan struktur organisasi merupakan media bagi manajer untuk mengendalikan, mempengaruhi kebijakan, anggaran dan mengorganisir arus informasi dalam organisasi.

Adanya struktur organisasi menunjukan aliran informasi, uraian pekerjaan, wewenang yang terlibat dalam lingkungan internal organisasi. struktur organisasi berpengaruh terhadap sistem informasi akuntansi keuangan dan manajemen dalam hal memfasilitasi tersediaanya informasi dan memperluas distribusi informasi untuk seluruh karyawan pada berbagai level organisasi, sehingga karyawan yang berada pada lebel yang paling bawah sekalipun dapat memberikan dorongan/kontribusi terhadap proses pengambilan keputusan, salah satu faktor yang dipertimbangkan ketika merancang sistem informasi akuntansi manajemen adalah struktur organisasi (Laudon dan Laudon , 2014).

Kontribusi struktur organisasi terhadap aplikasi keuangan telah diteliti oleh para peneliti terdahulu. Hasil penelitian yang dilakukan oleh (Kuraesin, 2016) membuktikan adanya pengaruh struktur organisasi terhadap kualitas Aplikasi keuangan. Begitupula penelitian yang dilakukan oleh (Anggadini, 2018) berhasil membuktikan struktur organisasi berkontribusi terhadap kualitas aplikasi keuangan. Kemudian hasil penelitian (Rachmawati, 2016) membuktikan implementasi struktur organisasi yang efektif dapat meningkatkan keberhasilan penggunaan aplikasi keuangan. 


\section{Hipotesis.}

Rumusan hipotesis dinyatakan sebagai berikut:

$\mathbf{H}_{1}$ : Budaya Organisasi berpengaruh positif terhadap kualitas Aplikasi keuangan pada perusahaan Perbankan BUMN di Kota Bandung

H2: Struktur Organisasi berpengaruh positif terhadap kualitas Aplikasi keuangan pada perusahaan Perbankan BUMN di Kota Bandung

\section{METODOLOGI}

Untuk dapat menggambarkan variabel yang diteliti serta menguji keterkaitannya penelitian ini menggunakan metode deskriptif dan verifikatif. Penelitian ini menggunakan variabel yang tidak dapat diobservasi secara langsung sehingga sumber data yang dipergunakan dalam penelitian ini adalah data primer yang pegumpulannya diperoleh dengan cara membagikan kuesioner kepada pengguna sistem informasi akuntansi di perusahaan bank bumn berkantor cabang di Kota Bandung.

Populasi dalam penelitian ini adalah pengguna aplikasi keuangan pada perusahaan Bank BUMN berkantor cabang di Kota Bandung yaitu sejumlah 4 Bank BUMN (BRI, BNI, BTN dan Mandiri) yang diasumsikan terdapat 20 orang pengguna (Back dan Front Office), sehingga ukuran popuasi dalam penelitian ini adalah 80 pengguna akhir. Sampel minimal dalam penelitian ini ditentukan dengan menggunakan rule of tumb sehingga ukuran sampel penelitian ini sejumlah 30 pengguna akhir, selanjutnya sampel dipilih secara acak dengan menggunakan teknik simple random sampling. Untuk menguji Data dalam penelitian ini akan dianalisis dengan menggunakan Model Persamaan Struktural (Structural Equation Model-SEM).

Teknik penalaran deduktif dan induktif digunakan untuk menganalisis data yang berhasil dikumpulkan oleh peneliti. Penalaran deduktif dalam penelitian ini dilakukan dengan menelaah berbagai referensi yang berkaitan dengan variabel yang diteliti, peneliti mengumpulkan teori-teori dan hasil penelitian sebelumnya sebagai dasar dalam mengembangkan model konseptual yang akan diuji. Penalaran induktif dilakukan oleh peneliti melalui proses berpikir logis yang diawali dengan pengamatan dan pengumpulan data untuk melakukan pembuktian dan menarik kesimpulan yang dapat digeneralisasikan secara umum berdasarkan fakta (dalam hal ini fenomena) yang bersifat khusus. 


\section{HASIL UJI STATISTIK}

Hasil Tanggapan Responden terkait Variabel Budaya Organisasi. Deskripsi kondisi budaya organisasi yang diimplementasikan oleh perusahaan perbankan BUMN di Kota Bandung selanjutnya diuraikan melalui tabel 1, berikut ini:

Tabel 1. Deskripsi Budaya Organisasi

\begin{tabular}{c|l|c|c|c}
\hline NO & \multicolumn{1}{|c|}{ Keterangan } & Skor & $\boldsymbol{\%}$ & Kriteria \\
\hline 1 & Inovasi dan Pengambilan risiko & 94 & 62,67 & Cukup baik \\
\hline 2 & Perhatian terhadap Detail & 105 & 70 & Baik \\
\hline 3 & Orientasi Hasil & 97 & 64,67 & Cukup baik \\
\hline 4 & Orientasi Orang & 109 & 72,67 & baik \\
\hline 5 & Orientasi Tim & 89 & 59,33 & Cukup baik \\
\hline 6 & Agresivitas & 100 & 66,67 & Cukup baik \\
\hline 7 & Stabilitas $\quad 93$ & 62 & Cukup baik \\
\hline & & 687 & 65,43 & Cukup baik \\
\hline
\end{tabular}

Sumber: SPSS, 2020.

Variabel budaya organisasi digambarkan oleh responden dalam kategori cukup baik (total score 687 atau 65,43\%). Kategori cukup baik menunjukan budaya organisasi belum dapat dikenali, dipahami serta dijalankan dengan baik oleh pengguna aplikasi keuangan Bank BUMN di Kota Bandung karena masih terdapat gap sebesar 34,57\%. Gap tersebut menunjukan implementasi Budaya Organisasi pada Bank BUMN di Kota Bandung belum optimal.

Tanggapan Responden mengenai Struktur Organisasi. Deskripsi kondisi struktur organisasi yang diimplementasikan oleh perusahaan perbankan BUMN di Kota Bandung selanjutnya diuraikan melalui tabel 2, berikut ini:

Tabel 2. Deskripsi Struktur Organisasi

\begin{tabular}{c|l|c|c|c}
\hline NO & \multicolumn{1}{|c|}{ Keterangan } & Skor & $\%$ & Kriteria \\
\hline 1 & Spesialisasi & 100 & 66,67 & Cukup baik \\
\hline 2 & Departementalisasi & 98 & 65,33 & Cukup baik \\
\hline 3 & Rantai Komando & 104 & 69,33 & Cukup baik \\
\hline 4 & Rentang Kendali & 97 & 64,67 & Cukup baik \\
\hline 5 & Sentralisasi dan Decentralisasi & 99 & 66,00 & Cukup baik \\
\hline 6 & Formalisasi $\quad$ Total & 95 & 63,44 & Cukup baik \\
\hline & & $\mathbf{5 9 3}$ & 65,88 & Cukup Baik \\
\hline
\end{tabular}

Sumber: SPSS, 2020.

Variabel struktur organisasi digambarkan oleh responden dalam kategori cukup baik (total score 593 atau 65,88\%). Kategori cukup baik menunjukan struktur organisasi belum 
dapat dikenali, dipahami serta dijalankan dengan baik oleh pengguna aplikasi keuangan Bank BUMN di Kota Bandung karena masih terdapat gap sebesar 34,11\%. Gap tersebut menunjukan implementasi struktur organisasi pada Bank BUMN di Kota Bandung belum optimal.

Deskripsi Kualitas Aplikasi Keuangan. Deskripsi kondisi Kualitas Aplikasi Keuangan yang diimplementasikan oleh perusahaan perbankan BUMN di Kota Bandung selanjutnya diuraikan melalui tabel 3, berikut ini:

Tabel 3. Deskripsi Kualitas Aplikasi Keuangan

\begin{tabular}{|c|c|c|c|c|}
\hline NO & Keterangan & Skor & $\%$ & Kriteria \\
\hline 1 & Ketersediaan & 96 & 64 & Cukup baik \\
\hline 2 & Keamanan & 106 & 70,67 & Cukup baik \\
\hline 3 & Pemeliharaaan & 81 & 54 & Cukup baik \\
\hline \multirow[t]{2}{*}{4} & Terintegrasi & 98 & 65,33 & Cukup baik \\
\hline & Total & 381 & 63,5 & Cukup baik \\
\hline
\end{tabular}

Sumber: SPSS, 2020.

Variabel aplikasi keuangan digambarkan oleh responden dalam kategori cukup baik (total score 381 atau 63,5\%). Kategori cukup baik menunjukan aplikasi belum sepenuhnya handal, terintegrasi dengan baik, aman, dan fleksibel sehingga belum sepenuhnya digunakan oleh pengguna aplikasi keuangan Bank BUMN di Kota Bandung karena masih terdapat gap sebesar 36,5\%. Gap tersebut menunjukan penggunaan aplikasi keuangan pada Bank BUMN di Kota Bandung belum sukses digunakan.

Hasil Analisis Verifikatif. Dalam Penelitian ini pengujian model pengukuran dilakukan setelah pengujian validitas dan reliablitas yang hasilnya telah teruji memenuhi persyaratan valid dan reliabel. Persamaan model struktural dalam penelitian ini dinyatakan dalam rumus sebagai berikut:

$$
\mathrm{Y}=0,433 \mathrm{X}_{1}+0,470 \mathrm{X}_{2}+\zeta
$$

Persamaan tersebut dapat diuraikan sebagai berikut:

koefisien jalur struktural budaya organisasi adalah 0,433 dan Struktur organisasi adalah 0,470 kondisi tersebut menunjukan variabel struktur organisasi memiliki pengaruh relative lebih besar terhadap kualitas Aplikasi keuangan dari pada variabel kualitas aplikasi keuangan. Arah korelasi bertanda positif menunjukan semakin meningkat efektifitas budaya organisasi dan struktur organisasi akan semakin meningkatkan pula kualitas penggunaan aplikasi keuangan yang digunakan entitas 4 Bank BUMN di Kota Bandung.

Hasil pengujian koefisien korelasi menunjukkan budaya organisasi berpengaruh terhadap kualitas aplikasi keuangan sebesar 35,90\% sedangkan sisanya sebesar $64,10 \%$ 
dipengaruhi oleh faktor lain yaitu struktur organisasi, politik, lingkungan sekitar dan keputusan manajemen (Laudon dan Laudon, 2017).

Besaran pengaruh struktur organisasi terhadap kualitas aplikasi keuangan sebesar $39,20 \%$ sedangkan $60,80 \%$ sisanya dipengaruhi oleh faktor lain yaitu pelaksaan tugas, peran dan tanggungjawab (Bodnar dan hopwood, 2014).

\section{Pengujian Hipotesis}

Pengujian Hipoteis 1: Pengaruh budaya organisasi terhadap Kualitas Aplikasi Keuangan. Hipotesis 1 dalam penelitian ini dapat terbuktikan berdasarkan nilai $t_{\text {statistik }}$ sebesar 2,279 lebih besar nilai $\mathrm{t}_{\text {kritis }}$ sebesar 2,052, $\mathrm{H}_{0}$ ditolak dan terima $\mathrm{H}_{\mathrm{a}}$, dengan kesimpulan budaya organisasi terbukti secara statistik berpengaruh signifikan terhadap Kualitas Sistem Informasi Akuntansi pada Bank BUMN di Kota Bandung.

\section{Pengujian Hipotesis 2: Pengaruh Struktur Organisasi terhadap Kualitas Aplikasi} Keuangan. Hipotesis 2 dalam penelitian ini dapat terbuktikan berdasarkan nilai $t_{\text {statistik }}$ sebesar 2,463 lebih besar nilai $\mathrm{t}_{\text {kritis }}$ sebesar 2,052, $\mathrm{H}_{0}$ ditolak dan terima $\mathrm{H}_{\mathrm{a}}$, dengan kesimpulan Struktur Organisasi terbukti secara statistik berpengaruh signifikan terhadap Kualitas Aplikasi Keuangan pada Bank BUMN di Kota Bandung.

\section{DISKUSI}

Pengaruh Budaya Organisasi terhadap Kualitas Aplikasi Keuangan. Penelitian ini secara statistic terbukti Budaya Organisasi berpengaruh positif signifikan terhadap Kualitas aplikasi keuangan dengan besaran pengeruh sebesar 35,90\%. Arah Hubungan positif menunjukan bahwa semakin meningkatknya pemahaman dan penerapan budaya organisasi dalam suatu organisasi maka akan meningkatkan pula penguasaan individu dalam penggunaan aplikasi keuangan.

Hasil penelitian ini mendukung teori yang telah dikemukanan (Turban dan Volonino, 2015) bahwa kualitas aplikasi keuangan (sistem informasi) ditentukan oleh kualitas keterikatan yang terjadi antara kualitas aplikasi yang digunakan dengan pengguna, proses bisnis dan budaya organisasi yang berlaku di organisasi tersebut dan dinyatakan pula oleh (Lilis, 2021) bahwa setiap entitas memiliki culture dan kabiasaan yang unik dan terdiri dari sekumpulan elemen seperti asumsi dasar, nilai, norma dan cara dalam melakukan sesuatu, yang diterima oleh seluruh anggota organisasi untuk mencapai tujuan perusahaan. Kultur organisasi menentukan arah, tujuan, strategi dan kebijakan perusahaan dimasa yang akan datang, termasuk penggunaan aplikasi di dalam perusahaan untuk membantu aktivitas operasional merupakan salah satu bentuk wujud dari implementasi dari budaya organisasi yang berlaku dalam suatu organisasi.

Hasil penelitian ini juga sejalan dengan penelitian yang dilakukan oleh (Rahayu et al., 2014), (Setyanusa, 2015), (A Khamis, 2018), (Lilis dan Nurshalihat, 2020) dan (HA Van Dung, 2020) yang berhasil membuktikan bahwa Budaya Organisasi memberikan kontribusi positif terhadap peningkatan kualitas penggunaan aplikasi akuntansi keuanga yang digunakan di berbagai berbagai perusahaan di berbagai Negara.

Hal ini menjawab adanya aplikasi keuangan yang masih sering bermasalah karena sering mengalami gangguan sistem yang menyebabkan sekitar 10\% nasabah Bank Mandiri pmengalami perubahan jumlah saldo di rekeningnya dan gangguan tersebut terjadi karena 
bank sedang melakukan pemindahan data dari core system ke backup system. Permasalahan tersebut sebetulnya dapat diantisipasi apabila perusahana membanguh budaya organisasi yang baik dengan cara memberikan pelayanan yang baik kepada para nasabahnya. Bank dapat memberikan informasi kepada nasabah sehingga nasabah merasa diberikan perlindungan dan kepastian layanan yang terjaga dengan baik dan terkendali, dimana bisnis perbankan yang melibatkan banyak nasabah perlu memiliki sistem ketahanan dalam operasional bisnisnya sehingga bank dapat dengan sigap dan cepat menjaga kualitas dan kontinuitas sistem operasinya dalam situasi dan kondisi apapun.

Pengaruh Struktur Organisasi terhadap Kualitas Sistem Informasi Akuntansi. Penelitian ini secara statistik telah membuktikan bahwa Struktur Organisasi berpengaruh positif signifikan terhadap Kualitas aplikasi keuangan dengan besaran pengeruh sebesar $39,20 \%$. Arah Hubungan positif menunjukan struktur organisasi yang efektif akan semakin meningkatkan kualitas aplikasi keuangan yang digunakan perbankan BUMN di Kota Bandung.

Hasil penelitian sejalan dengan teori yang digunakan sebagai landasan penelitian ini bahwa struktur organisasi berkontribusi penting dalam meningkatkan arus informasi dalam suatu aplikasi keuangan dan berguna dalam memfasilitasi ketersediaan dan memperluas jangkauan distribusi informasi ke berbagai tingkatan dalam suatu organisasi, sehingga karyawan-karyawan pada level terendah dapat berkontribusi pada proses pengambilan keputusan (Laudon dan Laudon, 2012). Demikian pula (Bodna et al., 2010) berpendapat bahwa s struktur organisasi adalah alat bagi manajer untuk mengendalikan dan mempengaruhi kebijakan, anggaran dan perencanaan dalam organisasi, dengan adanya sruktur organisasi yang efektif akan meningkatkan kualitas aplikasi keuangan dalam memberikan layanan informasi akuntansi bagi berbagai penggunanya teori tersebut senada dengan pernyataan yang dikemukakan oleh (Lilis, 2021), bahwa struktur organisasi berpengaruh terhadap kualitas aplikasi keuangan dalam dalam memperluas distribusi informasi sampai pada tingkat organisasi yang paling bawah dengan tujuan untuk dapat di gunakan oleh para pegawai pada tingkat yang lebih rendah dalam proses pengambilan keputusan.

Hasil penelitian ini mendukung penelitian terdahulu yang dilakukan oleh (Kuraesin, 2016), (Rachmawati, 2016), (Anggadini, 2018), (A Khamis, 2018), (Andesto dan Susanto, 2018), (Rapina, 2019), (Lilis dan Wisdayanti, 2020) dengan bukti empiris Struktur Organisasi berkontribusi positif terhadap kualitas aplikasi keuangan pada berbagai perusahaan.

Penelitian ini juga menjawab beberapa permasalahan yang sering dialami dalam penggunaan aplikasi keuangan dimana salah satunya terjadi pada Kementerian Perdagangan dalam kegiatan impor barang sistem yang digunakan yaitu Custom Excise Information System and Automation (CEISA) belum sepenuhnya terintegrasi dengan Portal Indonesia National Single Widow (INSW) dan belum menghasilkan data yang akurat karena aplikasi keuangan yang digunakan tidak memadai. Hal ini disebabkan oleh penerapan Struktur Organisasi yang kurang optimal. Akibatnya Standar operation Procedure (SOP) belum dapat berjalan dengan baik. Sehingga agar dapat meningkatkan Kualitas aplikasi keuangan maka Struktur Organisasi harus ditingkatkan dengan cara mengoptimalkan Standar Operational Procedure (SOP) yang berlaku dan mengintegrasikan Custom Excise 
Information System and Automation (CEISA) belum sepenuhnya terintegrasi dengan Portal Indonesia National Single Widow (INSW) agar dapat menghasilkan data yang akurat.

\section{KESIMPULAN}

Penelitian ini menghasilkan suatu kesimpulan bahwa: (1) Budaya Organisasi berpengaruh secara positif signifikan terhadap Kualitas Aplikasi keuangan, artinya Budaya Organisasi memberikan kontribusi dalam meningkatkan/menurunkan Kualitas aplikasi keuangan yang digunakan entitas bank BUMN di Kota Bandung, dimana semakin membaiknya Budaya Organisasi yang diterapkan maka Kualitas aplikasi keuangan yang digunakan perusahaan juga akan semakin meningkat demikian pula sebaliknya. Adanya masalah rendahnya Kualitas aplikasi keuangan karena kondisi Budaya Organisasi yang berlaku di perusahaan masih belum optimal. (2) Struktur Organisasi berpengaruh secara positif signifikan terhadap Kualitas Aplikasi keuangan, artinya Struktur Organisasi memberikan kontribusi dalam meningkatkan/menurunkan Kualitas aplikasi keuangan yang digunakan entitas bank BUMN di Kota Bandung, dimana semakin Efektifnya Struktur Organisasi yang diterapkan maka Kualitas aplikasi keuangan yang digunakan perusahaan juga akan semakin meningkat demikian pula sebaliknya. Adanya masalah rendahnya Kualitas aplikasi keuangan karena Struktur Organisasi yang berlaku di perusahaan masih belum digunakan secara efektif oleh anggota organisasi.

Saran. Sesuai dengan judul penelitian yang diteliti, maka penulis akan memberikan beberapa saran sebagai berikut: (1) Pada Budaya Organisasi maka yang harus diberikan fokus perhatian adalah pada indikator Agresivitas, dimana Budaya Organisasi yang diterapkan perlu terlibat dalam proses bisnis sistem pembayaran yang yang melibatkan banyak nasabah perlu memiliki ketahanan dalam sistem operasinya dan terus memperkuat rencana cadangan untuk mendukung bisnis. Dengan begitu perbankan dapat dengan sigap dan cepat untuk menjaga kualitas dan kontinuitas sistem operasinya dalam situasi dan kondisi apapun. (2) Pada Struktur Organisasi maka yang harus diberikan fokus perhatian adalah pada indikator Formalisasi, dimana Struktur Organisasi yang diterapkan perlu mengoptimalkan Standar Operasional Procedure (SOP) yang berlaku dan mengintegrasikan Custom Excise Information System and Automation (CEISA) belum sepenuhnya terintegrasi dengan Portal Indonesia National Single Widow (INSW) agar dapat menghasilkan data yang akurat.

\section{DAFTAR PUSTAKA}

Ahmad Susanto. (2013). Teori Belajar dan Pembelajaran di Sekolah Dasar. Jakarta: Kencana Prenadamedia Group.

Anastiasia Diana dan Lilis Setiawati. (2011). Sistem Informasi Akuntansi, Perancangan, Prosedur dan Penerapan. Edisi 1. Yogyakarta: Andi Yogyakarta.

Anggadini, Sri Dewi. (2018). The influence of the organizational structure and of the top management supports on the accounting information system and its implication on the accounting information quality. 
Arlis Dewi Kuraesin. (2016). Influence Organizational Structure on the Quality of Accounting Information Systems. Research Journal of Finance and Accounting. (Vol. VII, No. 2, 225- 234).

Azhar Susanto. (2013). Sistem Informasi Akuntansi. Bandung: Lingga Jaya.

Bodnar, George H, and Hopwood, William S. (2014). Accounting Information System. 11th Edition. Boston: Pearson Education. .

Bodnar, George H, and William S. Hopwood. (2010). Accounting Information System. 10th Edition. Boston: Pearson Education.

Campbell, David and Tom Craig. (2005). Organisations and the Business Environment, Second Edition 2nd Edition. Butterworth-Heinemann. United Kingdom.

Colquitt, Jason. A. (2015). Organizational Behavior. McGraw-Hill Education, United States Of America.

Daft, Richard L. (2010). Organization Theory and Design: Tenth Edition. South-Western: Cengage Learning.

De. Lone, William H and Ephraim R. McLean. (1992). Information System Success: The Quest for The Dependent Variable. Information System Research. 3 (1) (March). Pp.60-94.

De.Lone, William H and. (2003). Information Systems Success: TheQuest for the Dependent Variable. Information System Research The Institute of Mangement Science. Page. 15.

Deghanzade, Hamed; M.Ali Moradi and Mahvasan Ragibhi. (2011). A Survey Of Human Factors Impact on The effectiveness of AIS. 2011. International Journal Of Bussiness Administration. Vol 2. No.4.

Inta Setya Budi. (2015). Influence of Organizational Culture and Structure on Quality of Accounting Information System. International Journal of Scientific \& Technology Reasearch. (Vol. IV, 257-267).

Joseph F. Hair. (2014). Multivariate Data Analysis, New International Edition. New. Jersey: Pearson.

Kendall, K.E. dan Kendall, J.E. (2011). Systems Analysis and Design. 8th Edition. New Jersey: Pearson Education.

Khamis, Amran. (2018). Effect of the Organizational Culture and Structure on the Effectiveness of Accounting Information Systems. RESEARCH REVIEW International Journal of Multidisciplinary. Vol.03, No. 9. Pp. 209-302.

Kreitner Robert dan Angelo Kinicki. (2003). Perilaku Organisasi: Organizational Behavior. Jakarta: Salemba Empat.

Krismiaji. (2015). Sistem Informasi Akuntansi. Edisi 4. Yogyakarta: UPP STIM.

Laudon, K.C. and Laudon, J. P. (2012). Management Information System Managing in the Digital Firm, 12th Edition. London: Pearson Education.

Laudon, K.C. and Traver, C, G. (2017). E-Comerse 2016 Business, technology, society, 12th Edition. England: Britis Library Cataloguint-in.

Lilis Puspitawati dan Melina Wisdayanti. (2020). Kesuksesan Sistem Informasi Akuntansi yang Dipengaruhi oleh Optimalisasi Dukungan Manajemen Puncak serta Efektifitas Struktur Organisasi. Jurnal Riset Akuntansi Dan Keuangan, Vol. 8, No.3, Pp. 531540.

Lilis Puspitawati, dan Sri Dewi Anggadini. (2011). Sistem Informasi Akuntansi. Yogyakarta: Graha Ilmu. 
Lilis Puspitawati, Novi Indriani Siti Nurshalihat. (2020). Prediction Modal Kualitas Aplikasi Sistem

Lilis Puspitawati, Siti Kurnia R, dan Sri Dewi A. (2014). Analisis Budaya Organisasi pada Pengembangan Sistem Informasi di UNIKOM. Bidang Ekonomi, Majalah Ilmiah UNIKOM. (Vol. 12, No. 2, 203-210).

Lilis Puspitawati. (2021). Sistem Informasi Akuntansi: Kualitas dan Faktor lingkungan Organisasi yang mempengaruhi. edisi pertama. Rekayasa Sains. Bandung.

Lilis Puspitawati. (2021). Strategic Information Moderated By Effectiveness Management Accounting Information Systems: Business Strategy Approach. Jurnal Akuntansi Universitas Tarumanagara. Vol.25, No.1, Juni 2021.

Luthans, Fred. (2008). Organizztional Behavior. McGraw-Hill Companies, Inc.New York.

Mardi. (2016). Sistem Informasi Akuntansi. Bogor: Ghalia Indonesia.

Marshall B. Romney, dan Paul J. Steinbart. (2016) Sistem Informasi Akuntansi. Terjemahan Kikin Sakinah Mursafira dan Novita Puspa Sari. Jakarta: Salemba Empat.

Post, G. V and Anderson, D. L. (2003). Management Information Systems Solving Business Problems with Information Technology, Third Edition. Singapore: McGraw-Hill.

Rapina, Rapina. (2019). The Influence of Leadership and Organizational Structure on The Quality of Accounting Information System.Accounting and Finance Review. Vol. 3, No. 3. Pp. $58-63$.

Rima Rachmawati. (2016). Struktur Organisasi, Pengendalian Intern Terhadap Kualitas Sistem Informasi Akuntansi Manajemen. MIX: Jurnal Ilmiah Manajemen. (Vol. VI, No. 1, 70-82).

Roni Andesto and A Susanto. (2018). The effect of organizational structure on quality of management accounting information systems (Survey on Indonesia State-Owned Enterprise. Journal of Engineering and Applied Sciences. Vol. 13, No. 1. Pp.20622067.

Sacer, Ivana Mamic; Katarina Zager, Boris Tusek. (2006). Accounting Information System's Quality as The Ground for Quality Business Reporting. IADIS International Conference e-Commerce.

Stair, Ralph M and George Reynold. (2012). Fundamental of Information Systems.Sixth edition.USA: Cengage Learning.

Stephen P. Robbins, dan Mary Coulter. (2016). Management. 13th Edition. London: Pearson Education.

Stephen P. Robbins, dan Timothy A. Judge. (2015). Organizational Behavior. 16th edition. United State America: Pearson.

Stephen P. Robbins. Timothy A. Judge. (2018). Essentials of Organizational Behavior. Fourteenth Edition. UK: Pearson Education. Pg.296).

Sutrisno, Edy. (2015). Budaya Organisasi. Jakarta: Prenada Media.

Turban, E., dan Volonino, L. (2011). Information Technology for Management. Eight Edition. Unite States: Jhon Willey and Sons. Inc

Zahirul Haque. (2004). Strategic Management Accounting: Concept, Processes and Issues. Second Edition. USA: Spiro Press. 